\title{
Impact analysis of urban structure and the economic sustainability of public transport in the city of Murcia (Spain)
}

\author{
S. García-Ayllón \\ Technical University of Cartagena, UPCT, Spain
}

\begin{abstract}
One of the fundamentals of an efficient public transport system is economic sustainability. The poorly structured growth of cities sometimes leads to the difficulty to maintain urban transport systems for public administrations. An interesting example of this territorial problem in urban and intercity transportation is the city of Murcia, the capital of a municipality of nearly $900 \mathrm{~km}^{2}$ equipped with various multi-modal public transport networks. This city of over 400,000 inhabitants has a historically dispersed urban structure where the population spread has been aggravated in recent years by a strong urban growth. The accelerated development of the city, coupled with the current crisis and budgetary consolidation, has made some public systems of urban and intercity transport economically unsustainable.

This article analyzes the impact that the urban development of the city of Murcia has had on the various systems of urban and intercity transportation: car, bus, tram, suburban, etc. A diagnosis of the current problems and possible solutions for the future will be presented in order to stimulate an economically sustainable public transport strategy.
\end{abstract}

Keywords: public transport, urban structure, economic sustainability, Murcia.

\section{Introduction}

In the current climate of a global economic crisis, the economic sustainability of public services is crucial to the maintenance and proper functioning of the same factor. In the case of urban transport, economic sustainability is closely linked to cost criterion, as long as these tend to be heavily subsidized services by the public administration. 
In Spain, in this sense, there have been two complementary phenomena in recent decades whose consequences are surfacing now because of the economic crisis. On one hand, the growth of cities, the result of urban and real estate bubble, which translates into a greater, more dispersed population and requires a number of different public services, of which transportation is a key factor. On the other hand, it can be observed a greater tendency for the public subsidy in the field of urban transport, accompanied by parallel progressive politics commitment to multimodality (metro, tram, bus rapid transit, etc.).

This article will analyze the case of the city of Murcia, a city of 400,000 inhabitants located in the southeast Spanish, where the important population growth has accentuated an already dispersed urban structure. This urban destructuration makes it difficult to economically maintain the current public bus transport, whose viability has also entered in recent years to compete with the new tram lines.

\section{Urban structure of the city of Murcia: sprawl growth as an imbalance factor}

One of the main features to assess in a city when one makes its transport strategy is the nature of its urban structure [1]. In this field, there are basically two models linked to parameters of urban infrastructure growth and population dispersion: the "oil slick" model and urban sprawl model (Fig. 1).
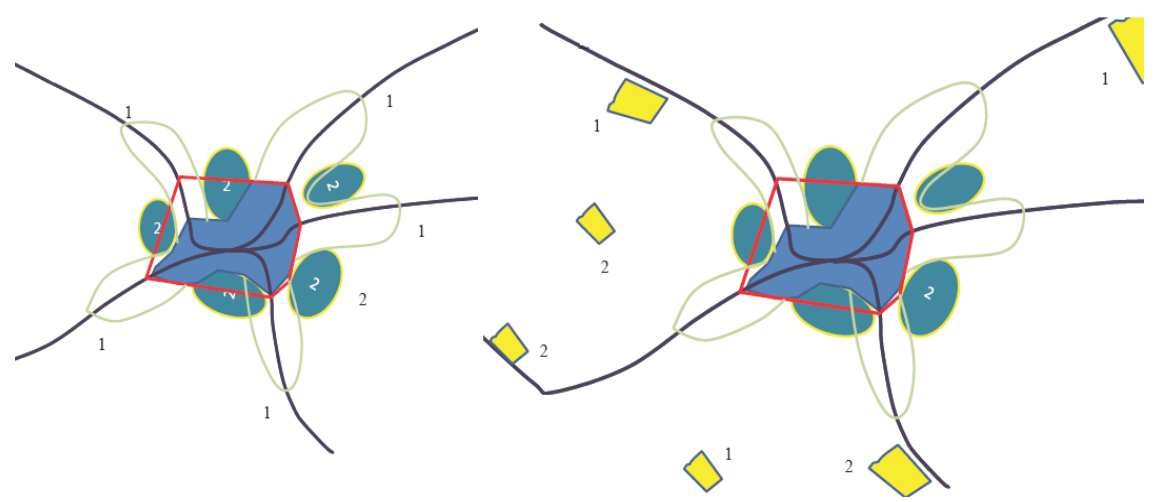

Figure 1: Urban model of "oil slick" (left) and sprawl model (right). Source: Miralles, J. L.

In the "oil slick" model, transport infrastructure structures the urban growth resulting from the city centre, with predictable cycles of population growth along land routes. This type of urban planning goes revaluing and silting soil interstitial spaces between nearby infrastructure. In the sprawl model, growth is multipolar, and it is growth who structures the transport infrastructure. Both models pose advantages and disadvantages. In the case of sprawl model, it is definitely a 
model that induces an urban structure but with a greater economic cost and energy maintenance, although it avoids better phenomena of real estate speculation with the ground [1].

It must be noted that this is a theoretical approach and in reality no city exemplifies $100 \%$ none of these models. In the case of Murcia, we have a strong city sprawl-oriented model, where only $40 \%$ of the population resides in the vicinity of the urban plot, the rest being distributed over more than 50 districts of a municipality of about $900 \mathrm{~km}^{2}$. This is the result of a poorly planned urban growth in the last 50 years, where for example, the consolidation of the former urban ring A-30 road has strangled the growth of the city to the west (Fig. 2). This phenomenon has generated such a dispersed pattern of small settlements, some of which are located more than $30 \mathrm{~km}$ from the city centre.

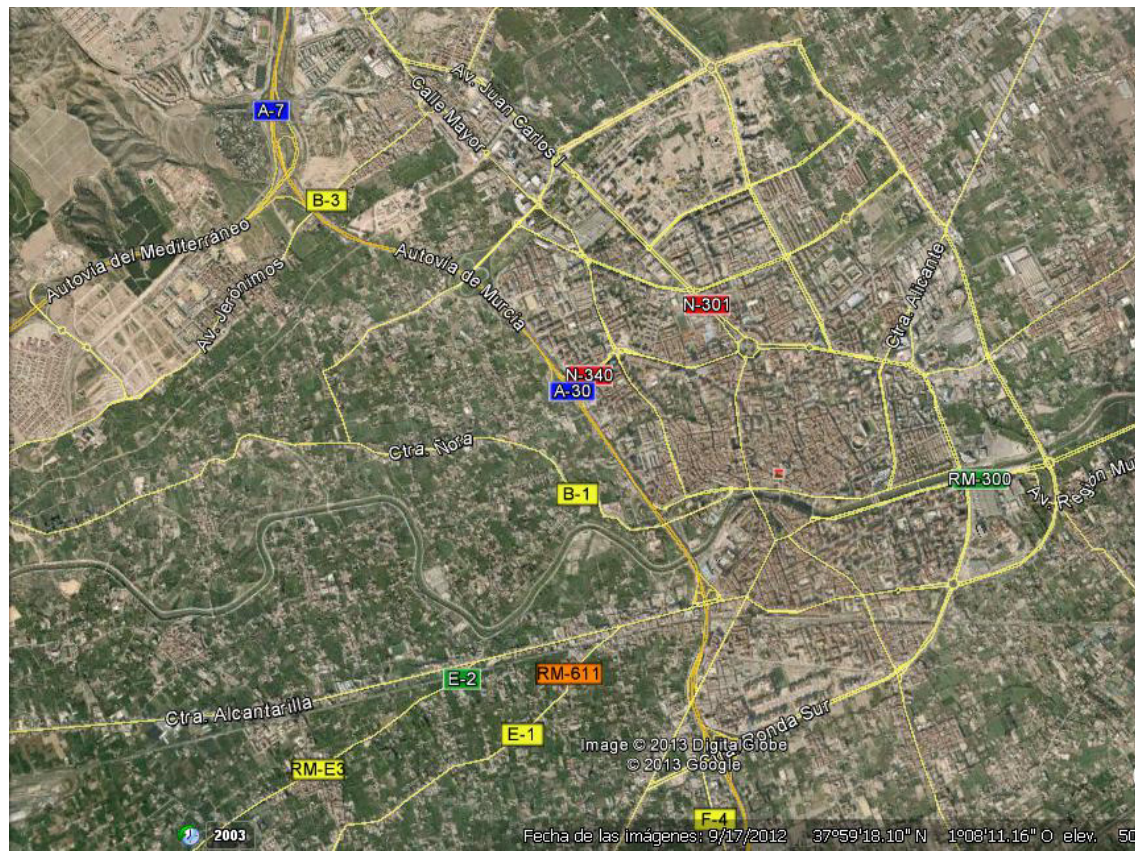

Figure 2: Physical structure of the urban area of the city of Murcia. Source: Google maps.

This urban structure becomes increasingly unsustainable with the development of resorts and consolidation of very peripheral settlements that require level of services similar to the city centre. In this way, the urban structure of the municipality is divided into many districts and boroughs with limited transport flows between them. This situation obliges concessionaires of transport services to perform a high number of operations to serve the entire population (Fig. 3). 


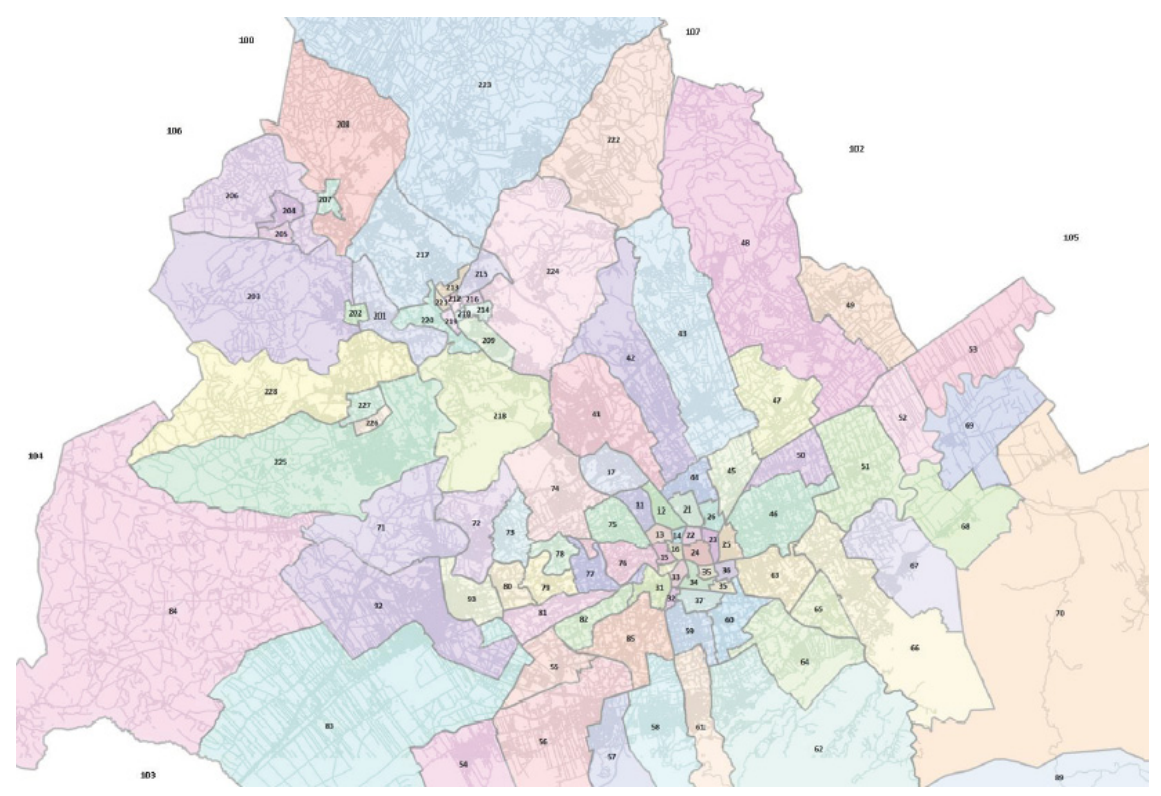

Figure 3: Districts and public transport areas in the municipality of Murcia. Source: [2].

These small settlements are linked by a dense and labyrinthine road network, built in many different section typologies. Thus, it coexist high capacity roads or highways bordering to the very centre of the city with characteristic streets of the historical centre with difficult access and pathways of different capacities, including areas of pedestrian use only. All this creates a complex and heterogeneous plot that complicates the treatment of the transport system of the city (Table 1).

Table 1: Summary by type of urban road in the municipality of Murcia. Source: [2].

\begin{tabular}{|l|c|}
\hline Road type & Total length $(\mathrm{km})$ \\
\hline Motorways state-owned & 150.43 \\
\hline Roads and highways of regional ownership & 27.27 \\
\hline High capacity intercity road & 224.99 \\
\hline High capacity metropolitan road & 613.50 \\
\hline High-capacity urban road & 72.25 \\
\hline Secondary urban roads & 705.57 \\
\hline Low-capacity urban road and rural road & $1,915.32$ \\
\hline Pedestrian road use only & 31.60 \\
\hline TOTAL & $3,740.93$ \\
\hline
\end{tabular}




\section{Sustainability analysis of public urban transport in the city of Murcia}

Among the different existing public transport systems in the city of Murcia (tram, bus and commuter rail), it is particularly interesting the case of interurban bus. This service is regulated by three administrative concessions of publicprivate partnership called MU-092, MU-93-I and MU-093-II, consisting of 35 bus routes covering populations in $900 \mathrm{~km}^{2}$ (Fig. 4).

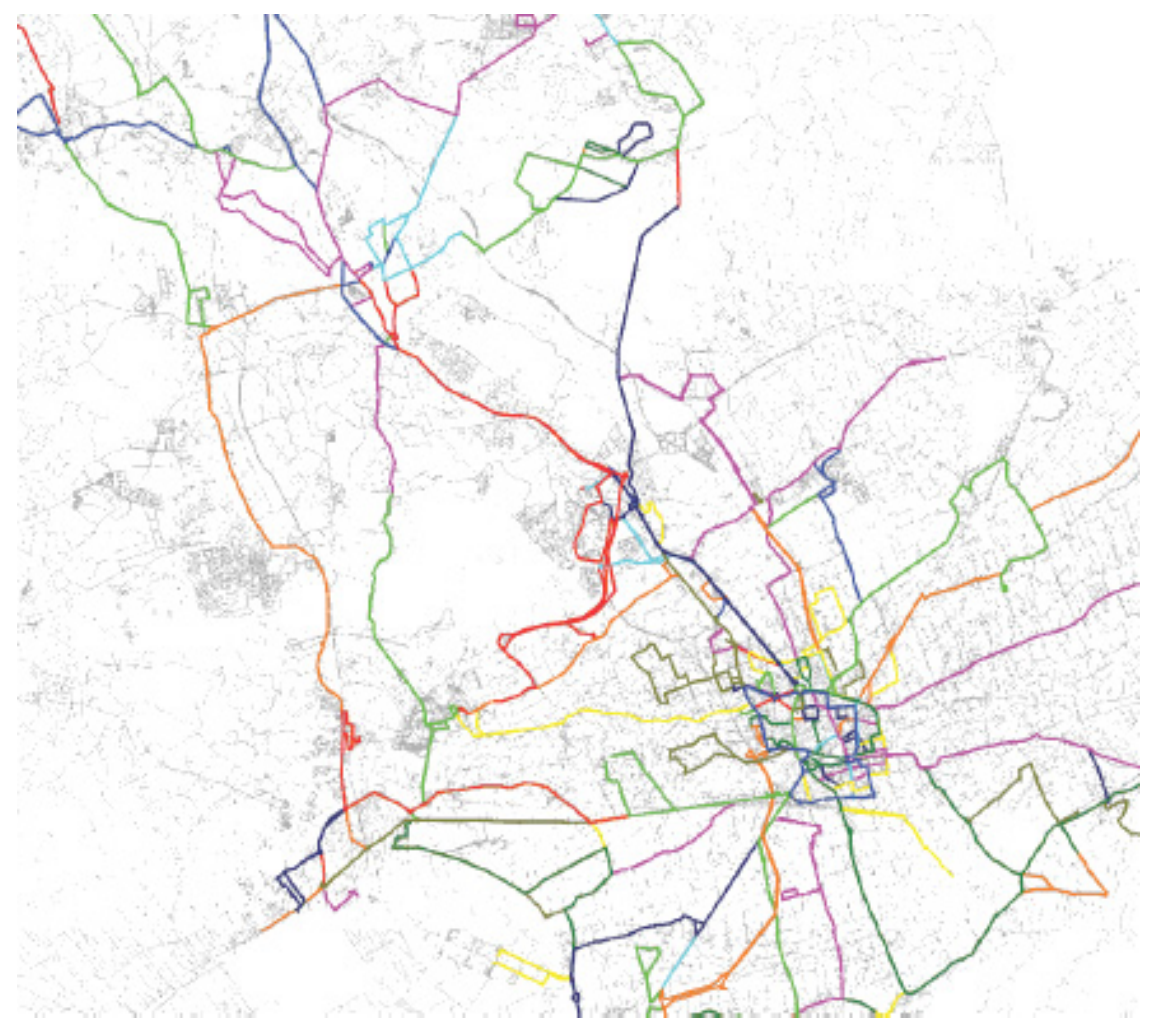

Figure 4: Sharing scheme of intercity bus lines MU-092 and MU-093 in the city of Murcia. Source: LATBUS S.A. [3].

If we analyze the economic and financial viability of these lines it can be seen that most of them (30 of 35) are deficient in the relationship between actual costs and benefits. Some of them are strongly deficient (economic returns less than $20 \%$ of cost), implying a possible wastage of under-utilization. If we analyze the total annual cost (26.7 million Euros) versus actual annual income (13 million Euros), it can be observed a strong imbalance as the ratio of cost coverage with real income barely reaches $50 \%$, with important economic losses in several bus lines (Fig. 5). 


\begin{tabular}{|c|c|c|c|c|c|c|}
\hline & Direct Cost & Total Cost & Travellers & real income & Public help & Deficit \\
\hline Line 42 & $733715 €$ & 10700416 & 292701 & $289672 \varepsilon$ & & $-780369 \varepsilon$ \\
\hline Line 43 & $150318 €$ & 214764 ह & 65908 & $65226 \mathrm{E}$ & & $-149538 €$ \\
\hline Line 45 & $47942 €$ & $83550 €$ & 8095 & $5975 €$ & & $-77575 €$ \\
\hline Line 70 & $814262 €$ & 11050336 & 161601 & $121201 \mathrm{E}$ & & -9838336 \\
\hline Line 72 & $229089 \varepsilon$ & 345972 ध & 66483 & 50527 है & & $-295445 €$ \\
\hline Line 46 & $40834 \mathrm{E}$ & $133488 \varepsilon$ & 12699 & $9524 €$ & & $-123964 €$ \\
\hline TOTAL MU-092. & $2016161 \varepsilon$ & $2952849 \mathrm{~d}$ & 607487 & $542126 \mathrm{e}$ & & -24107236 \\
\hline Line 1 & $1055091 €$ & 1592044 ह & 971626 & 854267 ह & $513997 \mathrm{E}$ & $-223780 €$ \\
\hline Line 6 & $527879 €$ & $799396 \varepsilon$ & 624269 & $507244 \varepsilon$ & $346474 \varepsilon$ & $54322 €$ \\
\hline Line 7 & 1273856 & $186126 \varepsilon$ & 60662 & $37142 \varepsilon$ & 541996 & $-94785 €$ \\
\hline Line 12 & $142051 €$ & $211826 \varepsilon$ & 216440 & $152061 \varepsilon$ & $40495 \varepsilon$ & $-19270 €$ \\
\hline Line 25 & $117041 €$ & $173501 \epsilon$ & 86673 & $45937 €$ & $19239 \varepsilon$ & $-108325 €$ \\
\hline Line 26 & $906843 \epsilon$ & 1378357 ह & 1503976 & $1202554 €$ & $254702 \varepsilon$ & $78899 €$ \\
\hline Line 28 & $482844 €$ & $698049 \varepsilon$ & 483691 & $399171 \epsilon$ & $80931 \mathrm{f}$ & $-217947 €$ \\
\hline Line 29 & $542169 €$ & $815692 €$ & 732891 & $565421 \varepsilon$ & $351587 \varepsilon$ & $101316 €$ \\
\hline Line 30 & $632599 €$ & $923514 €$ & 773053 & $658631 €$ & $498191 €$ & $233308 \varepsilon$ \\
\hline Line 31 & $881356 €$ & $1285536 \varepsilon$ & 1135640 & $955337 \varepsilon$ & $468872 \mathrm{E}$ & 1386746 \\
\hline Line 34 & 129275 E & $186438 \varepsilon$ & 49276 & $35228 \varepsilon$ & $16019 €$ & $-135191 €$ \\
\hline Líne 37 & $277583 €$ & 399381 ह & 182086 & $136072 \varepsilon$ & $50837 €$ & $-212472 €$ \\
\hline Líne 39 & $1104116 \varepsilon$ & $1775812 €$ & 892219 & $562098 \varepsilon$ & $405638 €$ & -8080766 \\
\hline Line 50 & $1396222 \mathrm{E}$ & $2104128 \varepsilon$ & 1567084 & $1159642 \mathrm{E}$ & $858772 \mathrm{f}$ & $-85714 \epsilon$ \\
\hline $\begin{array}{ll}\text { Line } 61 \\
\end{array}$ & $243334 €$ & 372015 ह & 203584 & 157821 E & $78550 \mathrm{E}$ & $-135644 €$ \\
\hline Líne 91 & $468147 \varepsilon$ & $681633 \epsilon$ & 505581 & $399470 \varepsilon$ & $193415 \varepsilon$ & $-88748 €$ \\
\hline Line 92 & 268957 ह & $402894 €$ & 207802 & $160468 \varepsilon$ & $112903 \mathrm{E}$ & $-129523 €$ \\
\hline TOTAL MU-093-I & $9302895 \mathrm{E}$ & $13986341 \mathrm{c}$ & 10196552 & $7988565 \mathrm{E}$ & $4344821 \mathrm{E}$ & $-1652956 \varepsilon$ \\
\hline Line 21 & $705749 €$ & $1000509 \varepsilon$ & 617143 & $607355 \varepsilon$ & $3215 \varepsilon$ & $-389939 €$ \\
\hline Line 22 & $723522 \mathrm{E}$ & 10641786 & 696598 & $619610 €$ & $1678 \varepsilon$ & $-442890 €$ \\
\hline Line 24 & $266703 €$ & 399497 ह & 156746 & 83076 ह & $6021 €$ & $-310400 €$ \\
\hline Líne 27 & $420079 €$ & $583612 €$ & 237611 & $211712 \varepsilon$ & $6222 \varepsilon$ & $-365678 €$ \\
\hline Line 36 & $686590 €$ & $1000686 \varepsilon$ & 525896 & $486514 \varepsilon$ & $46948 \mathrm{E}$ & $-467224 €$ \\
\hline Líne 38 & $94974 \varepsilon$ & $170398 \varepsilon$ & 42503 & $23560 \varepsilon$ & $951 \epsilon$ & $-145886 €$ \\
\hline Line 41 & $655791 \epsilon$ & $964422 \varepsilon$ & 442967 & $438383 \varepsilon$ & $1689 \varepsilon$ & -5243506 \\
\hline Line 44 & $1999419 \varepsilon$ & $3038464 €$ & 2307017 & $1761326 €$ & $1034691 €$ & $-242447 €$ \\
\hline Line 47 & $78418 €$ & $124141 \varepsilon$ & 58637 & $32250 \mathrm{E}$ & & $-91890 €$ \\
\hline Line 49 & $304526 \varepsilon$ & $429903 \varepsilon$ & 122990 & $109461 \mathrm{E}$ & & -3204426 \\
\hline Line 52 & $363120 €$ & $624832 \varepsilon$ & 351538 & $312869 \varepsilon$ & & $-311963 €$ \\
\hline Line 54 & $285991 €$ & $404213 \varepsilon$ & 140193 & $124772 \varepsilon$ & & $-279441 €$ \\
\hline TOTAL MU-093-॥ & $6584883 \mathrm{E}$ & $9804855 \mathrm{E}$ & 5699841 & $4810888 \mathrm{E}$ & $1101415 \mathrm{E}$ & -38925526 \\
\hline TOTAL MU-093 & $15887778 \mathrm{E}$ & $23791196 \mathrm{E}$ & 15896393 & $12799453 \mathrm{E}$ & $5446236 \mathrm{f}$ & -55455078 \\
\hline TOTAL & $17903939 \mathrm{E}$ & 26744045 ह & 16503880 & $13341579 \mathrm{C}$ & $5446236 \mathrm{E}$ & -79562316 \\
\hline
\end{tabular}

Figure 5: Study of current economic ratios of intercity transportation in Murcia MU-092 and MU-093. Source: [4].

This situation occurs in Murcia (but also in many other cities of Spain), and is leading to study for real needs to optimize the costs of urban transport. These studies focus on the reorganization of public transport services, while maintaining service coverage that lowers the current scope in ratios not exceeding 10-20\%. These proposals aim to increase the level of economic sustainability of public transport, making funding needs of government grant reduce their ratios from $50 \%$ to $30 \%$, a must situation as a result of the current scenario of economic crisis and fiscal consolidation in public finances. 
For Murcia, the study has focused on maintaining the highest service coverage ratio and minimum loss of real income by the grantee, in order to give maximum economic and social viability to the proposed reorganization. This work has been done following three criteria:

a. Hierarchization of lines, following the importance population settlements using arrays of supply and demand,

b. Adaptation by GIS tools of itineraries to the current urban structure of the city (obsolescence of some itineraries because socioeconomic changes) [4],

c. Removal of duplication taking advantage of synergies with other public transport systems that have similar performance lines (tram in the town and commuter in intercity routes).

With these criteria a GIS study of possible routes on the urban plot of the municipality was performed, taking a standard buffer covering of 300 meters (Fig. 6). The entire public transport system obtained, has represented spatially, a degree of coverage of the population above $86 \%$, which is a very high value, given the difficulties due to urban settlements distribution described above. So, $86 \%$ of the population, has a bus stop within $300 \mathrm{~m}$.

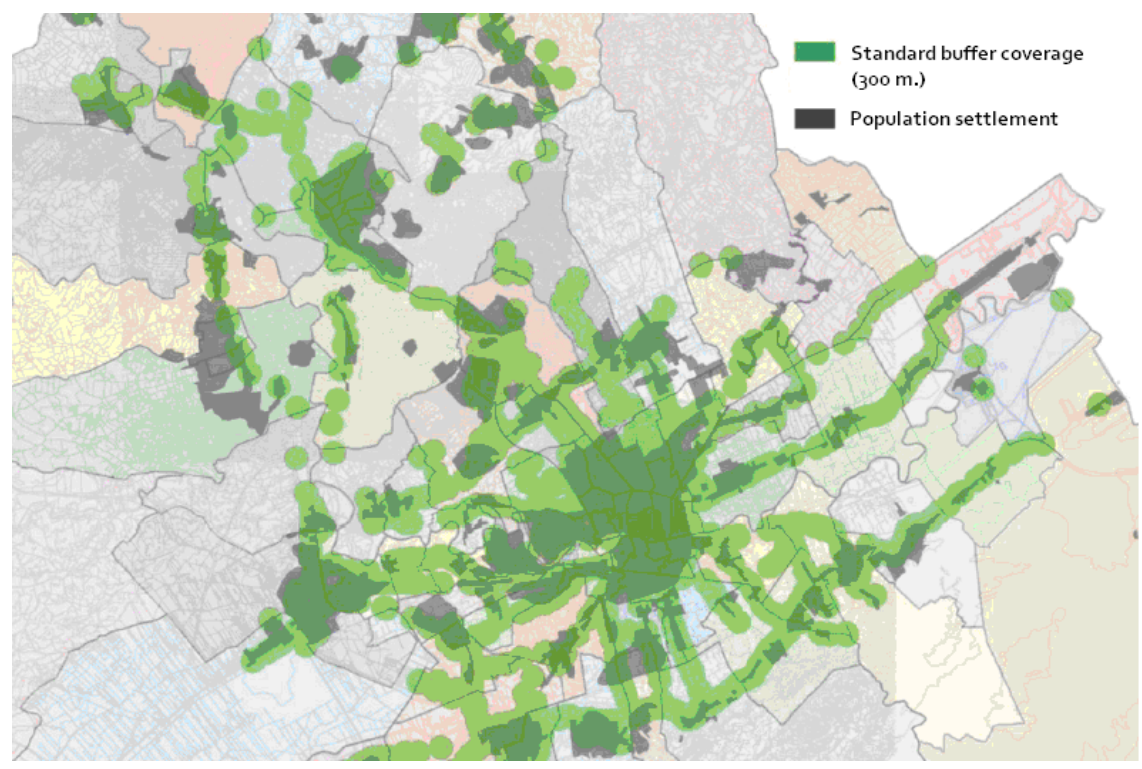

Figure 6: GIS analysis of population centres with coverage buffer of 300 meters in public transportation itineraries of urban and buildable land. Source: [5].

The economic and financial result of this proposal is more than significant. Despite the high rate of coverage, real costs have been reduced from 26.7 to 18.8 million Euros $(-30 \%$ cost), reducing the required general government grant to just 6.1 million. This is mainly because the new optimized proposal essentially 
maintains a level of very similar income of 12.7 million Euros (-4.5\%). This way, the city can get a more sustainable urban transport system whose real selffinancing rate goes from $50 \%$ to $66 \%$, significantly reducing the proportion and especially the amount of public subsidy (Fig. 7).

\begin{tabular}{|c|c|c|c|c|c|c|}
\hline & Direct Cost & Total Cost & Travellers & real income & Public help & Deficit \\
\hline Line 42 & $280851 \mathrm{E}$ & $422182 \mathrm{E}$ & 120395 & 1191496 & $=$ & $-303033 €$ \\
\hline Line 43 & $97289 \varepsilon$ & $116988 \mathrm{f}$ & 48900 & 48394 ह & - & -685946 \\
\hline Líne 45 & $47942 \mathrm{E}$ & $85537 \mathrm{E}$ & - & 06 & - & $-85537 €$ \\
\hline Line 70 & $465018 \varepsilon$ & $645920 \mathrm{E}$ & 109809 & 823576 & - & $-563563 €$ \\
\hline Line 72 & $180020 \hat{\varepsilon}$ & $296096 \varepsilon$ & 68973 & $52419 €$ & - & $-243676 \varepsilon$ \\
\hline Líne 46 & - & - & $=$ & $0 \varepsilon$ & - & $0 \varepsilon$ \\
\hline TOTAL MU-092 & $1071120 \varepsilon$ & $1566722 \mathrm{E}$ & 348077 & $302319 \varepsilon$ & - & $-1264403 \varepsilon$ \\
\hline Line 1 & $830381 \mathrm{E}$ & $1291268 \varepsilon$ & 974717 & $856985 €$ & $513997 \mathrm{E}$ & $79714 €$ \\
\hline Line 6 & 3651336 & $566437 \varepsilon$ & 245618 & $199575 \varepsilon$ & $346474 \varepsilon$ & -203896 \\
\hline Line 7 & - & - & - & - & - & - \\
\hline Line 12 & - & - & - & - & $=$ & - \\
\hline Line 25 & - & - & - & - & - & - \\
\hline Line 26 & $742258 \mathrm{E}$ & $1177131 \mathrm{E}$ & 1655834 & $1323977 \mathrm{\epsilon}$ & $254702 \varepsilon$ & $401548 €$ \\
\hline Line 28 & $380740 \varepsilon$ & $613600 \varepsilon$ & 551989 & $455535 €$ & $80931 €$ & $-77134 \varepsilon$ \\
\hline Line 29 & $461739 \varepsilon$ & $723573 \mathrm{E}$ & 1200653 & $926297 €$ & $351587 €$ & $554311 €$ \\
\hline Line 30 & $607319 \varepsilon$ & $952330 \mathrm{E}$ & 775669 & $660860 €$ & $498191 \mathrm{\epsilon}$ & $206721 €$ \\
\hline Line 31 & $881954 \varepsilon$ & $1337330 €$ & 1256995 & $1057425 \varepsilon$ & $468872 €$ & $188968 €$ \\
\hline Line 34 & - & - & - & - & $=$ & - \\
\hline Line 37 & $108159 \varepsilon$ & $168155 \varepsilon$ & 43354 & $32398 €$ & $50837 \mathrm{E}$ & -849196 \\
\hline Line 39 & $722787 \mathrm{E}$ & $1202628 \mathrm{E}$ & 675743 & $425718 €$ & $405638 \varepsilon$ & -3712726 \\
\hline Line 50 & $1392331 €$ & 21871426 & 1850029 & $1369022 €$ & $858772 €$ & $40651 €$ \\
\hline Line 61 & - & - & - & - & - & - \\
\hline Line 91 & $263536 \varepsilon$ & $410857 \varepsilon$ & 249733 & 1973196 & $193415 \varepsilon$ & $-20124 \varepsilon$ \\
\hline Line 92 & $216516 \varepsilon$ & $346787 \mathrm{E}$ & 75564 & $58352 \epsilon$ & $112903 \mathrm{E}$ & $-175532 €$ \\
\hline TOTAL MU-093. & $6972855 \mathrm{E}$ & $10977238 \mathrm{E}$ & 9555897 & 75634628 & $4344821 \mathrm{E}$ & $722544 \mathrm{E}$ \\
\hline Line 21 & $514754 \mathrm{E}$ & $764839 \mathrm{E}$ & 401914 & $395540 €$ & $3215 \varepsilon$ & $-366085 €$ \\
\hline Line 22 & $587769 \varepsilon$ & $865737 €$ & 992669 & $882959 €$ & $1678 €$ & $18899 \mathrm{E}$ \\
\hline Line 24 & $140902 \mathrm{E}$ & $216745 \mathrm{E}$ & 148627 & 787726 & $6021 €$ & $-131952 \epsilon$ \\
\hline Line 27 & - & - & - & - & - & - \\
\hline Line 36 & $501822 \mathrm{E}$ & $763958 \varepsilon$ & 479066 & 4431906 & $46948 \varepsilon$ & $-273820 €$ \\
\hline Line 38 & - & - & - & - & - & - \\
\hline Line 41 & - & - & - & - & - & - \\
\hline Line 44 & $1710563 €$ & $2616540 \varepsilon$ & 3363863 & 25681906 & $1034691 \varepsilon$ & 9863416 \\
\hline Line 47 & $78418 \varepsilon$ & $129341 \mathrm{E}$ & 43045 & $23674 €$ & - & $-105666 \varepsilon$ \\
\hline Line 49 & 272443 E & $386300 €$ & 269472 & 2398306 & - & $-146470 €$ \\
\hline Linea 52 & $319193 \mathrm{E}$ & $552216 \varepsilon$ & 285953 & $254498 \varepsilon$ & - & $-297718 \varepsilon$ \\
\hline Line 54 & - & - & - & - & - & - \\
\hline TOTAL MU-093. & $4125864 \mathrm{E}$ & $6295676 \mathrm{f}$ & 5984608 & $4886653 \mathrm{G}$ & $1101415 \mathrm{E}$ & $-316470 \varepsilon$ \\
\hline TOTAL MU-093 & 110987198 & $17272914 \mathrm{E}$ & 15540505 & $12450115 \mathrm{E}$ & $5446236 \mathrm{~g}$ & $406074 \varepsilon$ \\
\hline TOTAL & $12169840 \mathrm{E}$ & $18839636 \varepsilon$ & 15888582 & $12752435 \&$ & $5446236 \varepsilon$ & $-858330 €$ \\
\hline
\end{tabular}

Figure 7: Study of economic ratios with the new reorganization. Source: [6].

If we analyze the technical quality of the proposal disaggregating the analysis of the lines, it can be seen that the ratios of loss-making routes are generally offset by positive ratios in lines that did not have problems of economic viability. 


\begin{tabular}{|c|c|c|c|c|}
\hline Líne & Current & New & Difference & $\%$ Difference \\
\hline Líne 1 & 2835 & 2838 & 3 & $-0.11 \%$ \\
\hline Líne 5 & - & - & - & $0.00 \%$ \\
\hline Line 6 & 2089 & 949 & 1140 & $120.13 \%$ \\
\hline Líne 7 & 286 & - & 286 & $100.00 \%$ \\
\hline Líne 10 & - & - & - & $0.00 \%$ \\
\hline \begin{tabular}{|l|} 
Línea 12 \\
\end{tabular} & 610 & - & 610 & $100.00 \%$ \\
\hline Línea 21 & 1804 & 1225 & 579 & $47.27 \%$ \\
\hline \begin{tabular}{|l|} 
Line 22 \\
\end{tabular} & 2527 & 3730 & 1203 & $-32.25 \%$ \\
\hline Líne 24 & 456 & 421 & 35 & $8.31 \%$ \\
\hline \begin{tabular}{|l|} 
Line 25 \\
\end{tabular} & 307 & - & 307 & $100.00 \%$ \\
\hline Líne 26 & 5016 & 5646 & 630 & $-11.16 \%$ \\
\hline \begin{tabular}{|l|} 
Línea 27 \\
\end{tabular} & 1291 & - & 1291 & $100.00 \%$ \\
\hline Líne 28 & 1969 & 2166 & 197 & $-9.10 \%$ \\
\hline \begin{tabular}{|l|} 
Línea 29 \\
\end{tabular} & 2678 & 4121 & 1443 & $-35.02 \%$ \\
\hline Líne 30 & 2918 & 2965 & 47 & $-1.59 \%$ \\
\hline Line 31 & 3167 & 4484 & 1317 & $-29.37 \%$ \\
\hline Líne 34 & 226 & - & 226 & $100.00 \%$ \\
\hline Líne 36 & 1743 & 1514 & 229 & $15.13 \%$ \\
\hline Líne 37 & 778 & 155 & 623 & $401.94 \%$ \\
\hline Líne 38 & 324 & - & 324 & $100.00 \%$ \\
\hline \begin{tabular}{|l|} 
Line 39 \\
\end{tabular} & 7222 & 3390 & 3832 & $113.04 \%$ \\
\hline Líne 41 & 1880 & - & 1880 & $100.00 \%$ \\
\hline Líne 42 & 978 & 385 & 593 & $154.03 \%$ \\
\hline \begin{tabular}{|l|} 
Líne 43 \\
\end{tabular} & 111 & 207 & 96 & $-46.38 \%$ \\
\hline Líne 44 & 9450 & 11484 & 2034 & $-17.71 \%$ \\
\hline Líne 45 & 45 & - & 45 & $100.00 \%$ \\
\hline Líne 46 & 370 & - & 370 & $100.00 \%$ \\
\hline Líne 47 & 142 & 196 & 54 & $-27.55 \%$ \\
\hline Líne 49 & 422 & 780 & 358 & $-45.90 \%$ \\
\hline Líne 50 & 6241 & 6290 & 49 & $-0.78 \%$ \\
\hline Líne 52 & 1129 & 981 & 148 & $15.09 \%$ \\
\hline \begin{tabular}{|l|} 
\\
\end{tabular} & 517 & - & 517 & $100.00 \%$ \\
\hline \begin{tabular}{|l|} 
Líne 61 \\
\end{tabular} & 571 & - & 571 & $100.00 \%$ \\
\hline Líne 70 & 695 & 441 & 254 & $57.60 \%$ \\
\hline Líne 72 & 266 & 277 & 11 & $-3.97 \%$ \\
\hline Line 91 & 1242 & 878 & 364 & $41.46 \%$ \\
\hline $\begin{array}{ll}\text { Line } 92 \\
\end{array}$ & 794 & 282 & 512 & $181.56 \%$ \\
\hline TOTAL & 63099 & 55805 & 7294 & $13.07 \%$ \\
\hline
\end{tabular}

Figure 8: Current and new ratios of passengers by unbundled lines in the study. Source: [6]. 


\section{Conclusions}

The reorganization of existing systems of urban and intercity public transport (according to criteria of urban structure, population ranking service levels and leveraging synergies of multimodality), is a matter required by the economic situation in some cities in Spain. Public transport systems have to achieve higher self-financing ratios to educate the citizens of transport costs and be economically sustainable.

In this field, the correct coordination between land use planning and public transport is very important. In this paper, it can be seen how GIS tools have proven to be a very interesting instrument to adapt the old administrative public transport concessions to the changing reality from the point of view of urban planning and socioeconomic evolution.

The city of Murcia has an urban public transport system that suffers from a structural budget deficit driven by an urban sprawl model developed over the past 50 years. This model in the case of intercity public bus transport is increasingly unsustainable because the development of resorts and consolidation of peripheral settlements that require a similar level of service to the city centre. Implementing a coherent coordination among the urban structure of the city and its transportation systems, it has been achieved a rate of self-financing in the intercity public bus transport, whose ratio went from $50 \%$ to $66 \%$.

\section{References}

[1] Miralles i Garcia, J.L., García-Ayllón S. The economic sustainability in urban planning: case La Manga. WIT Transactions on Ecology and the Environment, Vol. 173, WIT Press: Southampton, pp 379-389, 2013.

[2] Urban planning service of the city of Murcia. Plan General de Ordenación Municipal de la ciudad de Murcia. Murcia City Hall, 1997.

[3] Traffic service of the city of Murcia. Plan de Movilidad Urbana de la ciudad de Murcia. Murcia City Hall, 2013.

[4] Entidad Pública del Transporte de la Región de Murcia S.A., LATBUS. S.A. Concesiones administrativas MU-092 y MU-093 de servicio de transporte público interurbano por autobús. Directorate-General for Transport of the Region of Murcia, 2009.

[5] García-Ayllón S. New analysis and diagnostic tools to improve governance in the context of urban planning and territorial management. International Journal of Sustainable Development and Planning. WIT Press: Southampton, 2014.

[6] Entidad Pública del Transporte de la Región de Murcia S.A., EPYPSA S.L. Propuesta de reordenación de las concesiones de autobús MU-092 y MU093. Ministry of Public Works and Planning of the Region of Murcia, 2011. 